Volume 6 Nomor 2, Agustus 2021, halaman 125 - 139.

\title{
Diagnostic Of Student Mathematics Ability On The Implementation Of Mathematics-Based Assessment Open-Ended Problems
}

\author{
Diagnostik Kemampuan Matematis Siswa Pada Implementasi Penilaian \\ Matematika Berbasis Open-Ended Problem
}

\author{
Benny Anggara \\ Mathematics Education Study Program, STKIP Yasika Majalengka, bennyangkara@gmail.com.
}

\begin{abstract}
ABSTRAK
Bentuk penilaian matematika yang dapat mengukur kemampuan matematis siswa secara pasti di tengah pembelajaran yang terdampak pandemi COVID-19 perlu dikembangkan. Pemberian tes diagnostik yang berbasis pada open-ended problem dapat menjadi salah satu solusi agar bentuk penilaian yang dilakukan tidak hanya mudah diterapkan tetapi juga mampu mengukur kemampuan matematis siswa secara tepat. Oleh karena itu, penelitian ini bertujuan untuk menganalisis kemampuan matematis siswa dalam implementasi asesmen berbasis open-ended problem. Penelitian ini menggunakan metode penelitian kualitatif dengan desain penelitian studi kasus. Penelitian ini dilakukan di salah satu sekolah yang berada di Kabupaten Cirebon dengan subjek penelitian sebanyak 50 orang siswa, yang terbagi dalam 15 responden berkemampuan matematis rendah, 20 berkemampuan sedang, dan 15 responden berkemampuan tinggi. Penelitian ini mengembangkan tiga buah masalah, yaitu masalah pada konsep aljabar, geometri, serta analisis data dan peluang. Berdasarkan hasil penelitian yang diperoleh dapat disimpulkan bahwa implementasi tiga masalah pada siswa dengan kemampuan matematis rendah dan sedang masih mengalami kesulitan dalam melakukan analisis dan membuat hubungan antar konsep yang disajikan pada masalah. Berbanding terbalik dengan responden yang berkemampuan matematis tinggi, kemampuan analisis dan kemampuan dalam membuat hubungan antar konsep yang disajikan mampu dibuat dan disusun dengan baik. Hal tersebut tercermin dari pengambilan keputusan terkait dengan prediksi solusi yang dibuat.
\end{abstract}

Kata Kunci : Tes diagnostik, Kemampuan Matematis, Open-Ended Problem.

ABSTRACT
It is important to implement a form of mathematical assessment that can measure students' mathematical abilities in the midst of learning affected by the COVID-19 pandemic. Providing diagnostic tests based on open-ended problems can be one solution so that the form of assessment carried out is not only easy to apply but also able to measure students' mathematical abilities accurately. Therefore, this study aims to analyze students' mathematical abilities in the implementation of open-ended problem-based assessments. This study uses a qualitative research method with a case study research design. This research was conducted in one of the schools in Cirebon Regency with 50 students as the subject of the study, which were divided into 15 respondents with low mathematical abilities, 20 moderate abilities, and 15 high ability respondents. This study develops three problems, namely problems in the concepts of algebra, geometry, and data and probability analysis. The results of the implementation of the three problems show that students with low and moderate mathematical abilities still have difficulty in analyzing and making connections between the concepts presented in the problem. In respondents who have high mathematical abilities, analytical skills and make relationships between concepts presented can be made and arranged well. This is reflected in the decision making related to the prediction of the solution made.

Keyword(s): Diagnostics Test, Mathematics Skills, Open-Ended Problem.

How to Cite: Anggara, B. (2021). Diagnostic Of Student Mathematics Ability On The Implementation Of Mathematics-Based Assessment Open-Ended Problems. Mathline: Jurnal Matematika dan Pendidikan Matematika, Vol. 6 No.2. 125 - 139.

DOI: https://doi.org/10.31943/mathline.v6i2.217 


\section{PRELIMINARY}

Mathematics learning is one of the subjects that has the largest portion in the allocation of lesson hours at the SMA/SMK level. This proves that students' mastery of mathematical concepts is an important requirement for students. Mathematics is seen as one of the sciences that shape the mindset of students to be able to reason, think creatively, and be able to solve problems. There are many challenges in mastering mathematical concepts, mathematics learning basically has abstract characteristics, as well as tiered concepts and principles (Wiryanto, 2020). Mathematics learning must be done with good planning, but currently the world is facing Coronavirus Diseases (COVID-19) so that it can trigger problems related to students' mathematical abilities.

The spread of COVID-19 has made learning that is usually done at school stopped and diverted by learning from home. Learn from home by utilizing the application of technology through the application of online and offline learning. The existence of this condition is a challenge for an educator. Educators must be able to learn in utilizing technology in the application of daily learning.Yusliardi \& Somakim (2015) the implementation of learning during the COVID-19 pandemic must prepare materials, use teaching aids and learning media that must be adapted to the level of intellectual development of students. This is important to be considered by the teacher so that student competencies can still be mastered so that learning objectives are achieved. In these conditions, students' competence in solving problems must be the focus so that the successful achievement of learning outcomes can be achieved.

Improving students' problem solving skills is the main goal in learning mathematics. Djahuno (2016) In solving mathematical problems, students not only use the mathematical abilities that students already have, but also increase their knowledge and deep understanding of certain mathematical concepts. The challenge in designing mathematical problem items that can get a comprehensive picture of students' mathematical abilities is an important thing to do in current conditions. This ability is an activity to diagnose students' mathematical abilities (Budget, 2020).

Given the success in a learning process can be seen from the mastery of concepts and achievement of learning outcomes which are reflected through the assessment of learning outcomes. One alternative to the preparation of diagnostic tools is to present problems that provide opportunities for students to provide many solutions to problems with many problem-solving strategies. According toRuslan \& Santoso (2013) that the 
variety of responses given by the students, the teacher can detect the thinking ability of the students. This type of problem is included as an open-ended problem.

Open-ended problem according to (Suherman \& et al, 2003) has advantages, one of which is that students have more opportunities to utilize their mathematical knowledge and skills as a whole, so that even students with low mathematical abilities can respond to problems presented in their own way. Giving open-ended problems according to (Shimada \& Becker, 1997); (Nohda, 2000) in learning mathematics can stimulate students' thinking skills and students' creativity. Giving open questions, such as open-ended problems, can provide opportunities for students to improve their way of thinking through freedom in expressing the results of their exploration of reasoning power and analysis (Heddens \& Speer, 2000); (Mustikasari et al., 2013). Therefore, the application of open-ended problems as a diagnostic tool is expected to provide a clear picture for teachers about their students' mathematical abilities.

Diagnostic tests have two main functions related to the evaluation of the learning process, first in identifying problems or errors experienced by students. Second, plan follow-up efforts in the form of solving efforts according to problems or errors that have been identified (Hadi et al., 2015). (Alderson \& Huhta, 2005) explained that diagnostic test kits should have six characteristics, namely (1) displaying indicators of the ability to be achievedstudents; (2) competency indicators that have not been achieved by students can be accessed through the implementation of diagnostic tests; (3) the implementation of diagnostic tests can lead students to be able to learn competency indicators that have not been achieved; (4) the results of diagnostic tests can be directly given feedback from students to improve competency achievement; (5) the results of the diagnostic test can be directly known to students after the students implement the test, and (6) the problems in the diagnostic test can measure the achievement of student competencies in depth. Based on the above, the flow of the preparation of the diagnostic test begins with the analysis of the most difficult ability indicators to achieve, then the implementation of the test, and providing feedback on the results of the implementation of the diagnostic test.

Open-ended problem is an assessment tool that contains problems that have many correct answers and strategies (Shimada \& Becker, 1997). A problem can be said to be open, i.e. an open solution process means that the problem emphasizes different settlement strategies to find a solution (Becker, 2006). This open end result implies that the problem has a different final answer. Different ways to develop, meaning that the questions emphasize how students can develop new questions based on the initial questions 
given.Ruslan \& Santoso (2013) explained that open-ended problems in mathematics can be grouped into two types, namely problems with one answer, many ways of solving and problems with many ways of solving and also many answers. Based on this explanation, it can be concluded that the open-ended problem is a problem in mathematics that requires students to provide many solutions, both with one answer and many answers.

Characteristics of open-ended problems developed based on (Sawada et al., 1997) that is; (1) Finding relationships, meaning that the problem is presented so that students are able to find some rules or relationships mathematically. (2) Classifying, meaning that the problems are presented so that students are able to classify problems based on the characteristics of certain objects to formulate certain concepts. (3) Measurement, meaning that the problem is presented so that students are able to determine numerical measures of certain events. In this study, open-ended problems are arranged based on the indicators described (Sawada et al., 1997) through problems that have many ways of solving and many answers to enable students to develop their creativity and thinking power. Based on the explanation above, this study aims to determine students' mathematical abilities through the implementation of open-ended problem-based diagnostic tests.

\section{METHODS}

This research was conducted to diagnose students' mathematical abilities through the implementation of open-ended problems. Based on these objectives, the research method in this study uses qualitative research methods with a case study research design.Qualitative research using a case study research design means that research is focused on a few selected phenomena and wants to be understood in depth by ignoring other phenomena, in this case to determine students' mathematical abilities using diagnostic tests based on open-ended problems.

In this study, respondents were divided into three mathematical abilities, namely respondents with low, medium, and high mathematical abilities. The division of mathematical abilities is based on learning outcomes obtained from the results of assessments conducted by teachers related to previous mathematics learning which is also strengthened by the results of the pretest before the study. The questions given during the pretest were related to the prerequisite concepts of algebra and geometry problems. The research subjects in this study were 50 students in one of the public high schools in Cirebon Regency,The subjects taken in this study came from three different abilities, 
namely 15 students with high math abilities, 20 students with moderate math abilities, and 15 students with low math abilities.

This research was conducted in April 2021. The data collection technique in this study used triangulation techniques, in the form of tests, interviews, and documentation. The test developed in this study uses a diagnostic test that develops a form of problem based on open-ended problems. The flow of the research carried out is adjusted to the scheme of preparing the diagnostic test kit, starting from the analysis of indicators of mathematical ability that are difficult to achieve, implementing diagnostic tests for students with different levels of mathematical ability, finally analyzing the feedback from the results of the diagnostic tests given to see the mathematical abilities of students who are grouped according to three different mathematical abilities.

\section{RESULTS AND DISCUSSION}

Refers to the flow of preparation of diagnostic tests adapted from (Alderson \& Huhta, 2005) This research begins by analyzing the indicators of mathematical ability which are still a weakness for students. Sources of information used by researchers in analyzing the indicators of the weakest mathematical ability, one of which is using the results of teacher assessments, reviewing previous findings, and conducting interviews on research subjects. The indicators of mathematical ability that are intended to be mapped are the ability to understand algebra, mastery of geometric concepts, ability in data analysis and probability science. In each of these indicators it can be seen that the student difficulty index is very high. The results obtained from these calculations are shown in table 1 below.

Table 1. Students' Mathematics Difficulty Index

\begin{tabular}{cc}
\hline $\begin{array}{c}\text { Indicator } \\
\text { Ability }\end{array}$ & $\begin{array}{c}\text { Index Score } \\
\text { Difficulty }\end{array}$ \\
\hline Understanding in Algebraic Concepts & $78 \%$ \\
Mastery of geometric concepts & $82 \%$ \\
Data and opportunity analysis skills & $72 \%$ \\
\hline
\end{tabular}

Based on table 1, it can be seen that the three indicators of mathematical ability are the weakest indicators for students. The ability of students' algebraic concepts is still weak, it can be seen from the weak understanding of students in understanding random variables. This is in line with (Anggara \& Wandari, 2021) that many students have difficulty in solving problems related to algebra, both in simple and complex forms. It can be seen from 
the number of students who experience conceptual misconceptions when solving HOTS questions about algebra. This is triggered because students cannot understand that a variable is a number whose value is unknown, so students cannot operate algebraic forms properly. While on (Wandari \& Anggara, 2021) students' weaknesses in understanding algebra have a major impact on other mathematical abilities, resulting in low understanding of mathematical concepts at the high school level. Therefore, the ability to understand students' algebra is important to be used as a key indicator of mastery of students' mathematical abilities.

The indicator of mastery of geometric concepts which includes concepts on flat shapes and spatial shapes is one of the indicators that needs to be developed in this test device considering the very large student difficulty index score. The weakness of students in mastering the concept of geometry is also shown by the weakness of the depiction of concepts related to geometric shapes. Anggara \& Wandari (2021) Many find misconceptions that cause students to have difficulty in geometric concepts, one of which is due to the existence of theoretical misconceptions. In line with (Menis \& Fraser, 1992); (Suparno, 2013) states that misconceptions as inaccurate understanding of concepts, incorrect use of concepts, incorrect classification of examples, confusion of different concepts and incorrect hierarchical relationships of concepts. This can explain that the student has misconceptions in solving geometry problems.

Analysis ability Data and opportunities need to be developed for students, this is because errors in opportunities can have an impact on making important decisions and developing students' thinking processes (Budget, 2019). In the field, it was also found that the ability of students in analyzing data and opportunities was also very low, this was due to the low ability of students to use their thinking concepts on contextual problems. One of them is that students have difficulty in making mathematical models of probability problems, this is in line with (Anggara et al., 2018) that the difficulty of students in compiling a mathematical model of the problem of opportunity resulted in the emergence of epistemological learning barriers.

Based on the results of the analysis of students' mathematical abilities, this study developed a set of diagnostic tests related to the concepts of algebra, geometry, statistics and probability. The problems developed in the diagnostic test kit are based on open-ended problems. Problems are made to detect how students' mathematical abilities in solving mathematical problems through taking solutions from students. Questions are also taken and adapted from the results of the research (Pelfrey, 2000). Students' mathematical 
abilities will be illustrated by analyzing the solutions given. The open-ended problem in this tool develops students' mathematical thinking processes by developing relevant rubrics.

The first problem is about the concept of algebra which requires students to find solutions by developing several alternative solutions and ways. Algebraic forms that contain a certain variable are sometimes considered a rigid symbol and are not a substitute for a number. Through the problems presented, measure the extent to which students understand algebraic concepts as a whole.

Find the positive integers $x$ dan $y$ that satisfy the following equation.

$$
x^{2}-y^{2}+x-y=10
$$

Figure 1. Problems about Algebraic Concepts

Based on Figure 1, students are asked to determine two magnitudes of a variable. The way that can be done to solve the problem is using direct substitution or by using manipulation in its algebraic form. When students take the method by direct substitution, there are several obstacles that might make it difficult, one of which is choosing numbers according to a random way which will take longer. How to manipulate algebraic forms first is the most effective way to solve this problem, but sometimes students find it difficult to make an approach that facilitates the problem solving process. The form of the approach that can be given by changing the form $x^{2}-y^{2}+x-y$ becomes $x(x+1)-y(y+1)$. This problem becomes much simpler. The form $x(x+1) y(y+1)$ and is the product of two consecutive numbers. The product of the two smallest positive integers is 2, 6, 12, 20, 30,42 , and so on. Based on the results of the analysis there are two possible solutions.

\begin{tabular}{|c||c|}
\hline $3(3+1)-1(1+1)=10$ & $5(5+1)-4(4+1)=10$ \\
So, $x=3$ and $y=1$ & So, $x=5$ and $y=4$ \\
Solution 1 & Solution 2 \\
\hline
\end{tabular}

Figure 2. Solution of Problems about Algebraic Concepts

Based on Figure 2, it can be seen that there are two solutions given, although the method used there uses an algebraic manipulation approach. Even if the solution is done by direct substitution, it will produce the same solution. Changing the shape of the problem to a simpler one will help the process of solving this, which requires an understanding of students' concepts that are not simple. Solution 1 is a form of solution that is likely to be 
easily accessible by students because it uses numbers that are not large, namely 3 and 1 . The choice of 3 as the value of $\mathrm{x}$ and $\mathrm{y}=1$ at least does not require much larger numbers when performing direct substitution. There is a key that students should understand in using this direct substitution method, where the value of $\mathrm{x}$ must be greater than the value of $\mathrm{y}$ so that the form of the equation remains positive. In solution 2, using a relatively large number, but it is still possible to access it because it involves two consecutive numbers, namely 5 and 4 . The results of the implementation of this problem are obtained as follows.

Table 2. Results of Implementation of Algebra Problems

\begin{tabular}{cccc}
\hline Solution Type & $\begin{array}{c}\text { Low Ability } \\
\text { Respondents }\end{array}$ & $\begin{array}{c}\text { Medium Ability } \\
\text { Respondent }\end{array}$ & $\begin{array}{c}\text { Highly Skilled } \\
\text { Respondents }\end{array}$ \\
\hline 0 (wrong answer) & $87 \%$ & $45 \%$ & $0 \%$ \\
1 & $13 \%$ & $40 \%$ & $67 \%$ \\
2 & 0 & $15 \%$ & $33 \%$ \\
\hline
\end{tabular}

Based on table 2, it can be seen that most of the students answered using solution 1. Most of the others were not able to answer the problem correctly. The ability of students to answer this problem using direct substitution by conducting random experiments on several numbers. Table 3 below shows the results of interviews with several respondents.

Table 3. Results of Interviews with Respondents when Algebra Problem Implementation

Medium Ability Respondent

Researcher: "how do you get the values of $\mathrm{x}$ and $y$ ?"

R25: "I factored the shape $x^{2}-y^{2}+x-y$ so $x(x+1)-y(y+1)$

"Then I see that the shape is a sequential number like $x$ with $(x+1)$ "

Researcher: "how do you know the value of $x$ is 3?"

R25: "I'll just try to use the logic of that sequential number"

Students with high mathematical abilities, one of which is represented by R41, finds solution 1 , by direct substitution where students are able to state that the value of $y$ must be smaller than the value of $x$. students choose the value of $y=1$ as the initial test and find a solution for the value of $\mathrm{x}$ to solve the equation. Students who are able to find solution 2, one of which is represented by R25, is able to explain the solution using the concept of algebraic manipulation so that the multiplication form between the terms has a unique pattern. The pattern is in the form of two consecutive integers. 
The responses given by students through the first problem showed that students' algebraic abilities were still quite limited. This is indicated by the inability of respondents with high mathematical abilities to find the relationship between the algebraic forms presented in the problem. In addition, the ability of students through the application of problem 1 explains that there are some students who are able to argue about number patterns and their characteristics, although most of them are difficult to determine.

The next problem relates to students' ability to solve problems about geometric concepts. The problem is related to the ability to measure angles by using the rules of an equilateral triangle. There are several abilities that are tested in this problem, not only the ability to measure angles, but there is a concept of comparison that is used to determine the final result. Here is the form of problem 2.

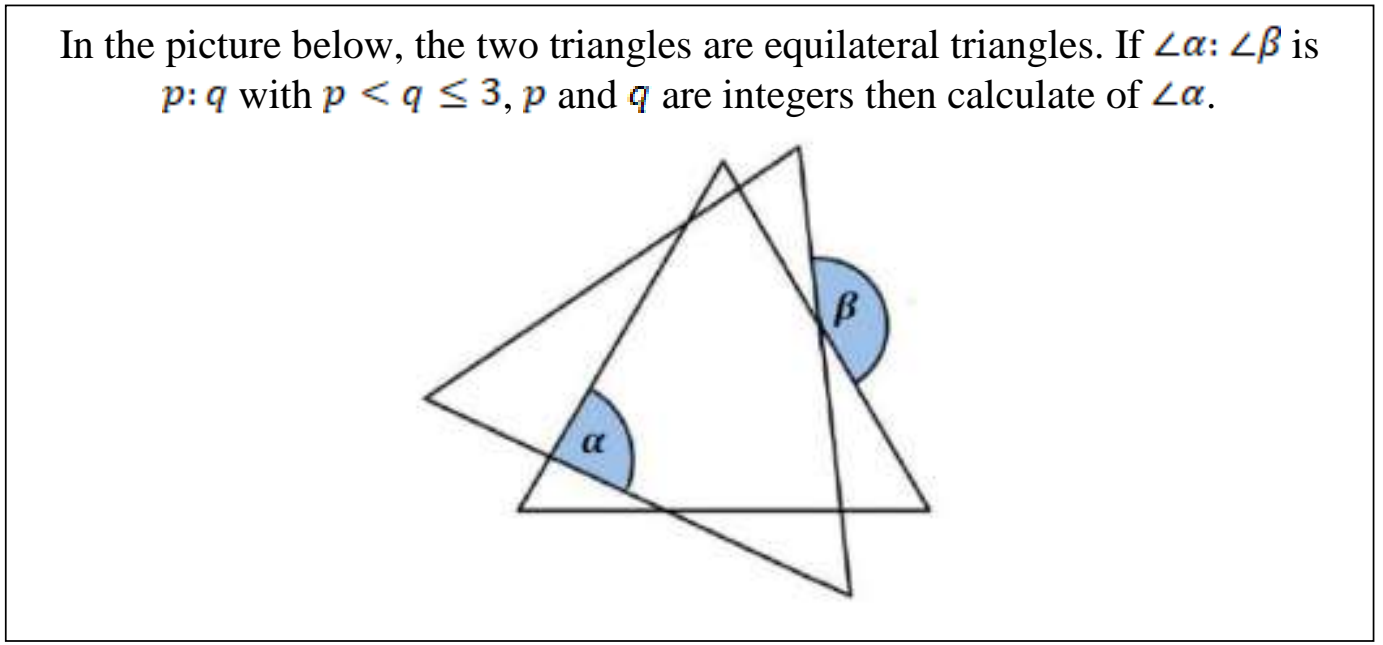

\section{Figure 3. Problems with Geometry Concepts}

In Figure 3, the presented geometry problem related to the measurement of this angle requires students to master the concepts and rules in triangles. The concept implied in the problem is the measure of the angles in an equilateral triangle and the sum of the angles in the triangle. It is important to link the two concepts to find the relationship between the angle quantities $\alpha$ and $\beta$. The relationship between angular quantities $\alpha$ and $\beta$ is the main key in solving the above problems. The relationship obtained by relating the concept of the angles of an equilateral triangle to the sum of the angles in the triangle is $\angle \alpha+\angle \beta=240^{\circ}$. The terms of the comparison of the two angles written in the problem are used as the final determinant in solving this problem. The following forms of solutions that can be made based on the comparison value. 


\begin{tabular}{|c||c|c|}
\hline Comparison taken & Comparison taken & Comparison taken \\
$\angle \alpha: \angle \beta=p: q=1: 3$ & $\angle \alpha: \angle \beta=p: q=2: 3$ & $\angle \alpha: \angle \beta=p: q=1: 2$ \\
Because, $\angle \alpha+\angle \beta=240^{\circ}$ & Because, $\angle \alpha+\angle \beta=240^{\circ}$ & Because, $\angle \alpha+\angle \beta=240^{\circ}$ \\
Then & Then & Then \\
$\angle \alpha=\frac{1}{4} \cdot 240^{\circ}$ & $\angle \alpha=\frac{2}{5} \cdot 240^{\circ}$ & $\angle \alpha=\frac{1}{3} \cdot 240^{\circ}$ \\
$\angle \alpha=60^{\circ}$ & $\angle \alpha=96^{\circ}$ & $\angle \alpha=80^{\circ}$ \\
& & \\
Solution 1 & Solution 2 & Solution 3 \\
\hline
\end{tabular}

Figure 4. Solution of Problems about Geometry Concepts

Based on Figure 4, the right solution in solving the problem is divided into three choices. Each of these choices is obtained from three possible comparisons between the two angles which states that $p<q \leq 3$, so that the possible comparison forms are 1: 3,2 : 3 , and 1: 2 . a ratio of $1: 3$, this is because the form of inequality presented directly limits the value of $q$ to a maximum of 3 . While the form of a solution that may be difficult to imagine is to take a comparison value of $1: 2$. The key in taking the solution to this problem is actually in the depiction of the relationship between the two angles so that get an equation $\angle \alpha+\angle \beta=240^{\circ}$. Therefore, the form of all the solutions given does not characterize any particular mathematical ability, only shows how accurate students are in describing all the relationships between the concepts presented. Here are the answers from all respondents.

Table 4. Results of Implementation of Geometry Problems

\begin{tabular}{cccc}
\hline Solution Type & $\begin{array}{c}\text { Low Ability } \\
\text { Respondents }\end{array}$ & $\begin{array}{c}\text { Medium Ability } \\
\text { Respondent }\end{array}$ & $\begin{array}{c}\text { Highly Skilled } \\
\text { Respondents }\end{array}$ \\
\hline 0 (wrong answer) & $100 \%$ & $50 \%$ & $20 \%$ \\
1 & $0 \%$ & $25 \%$ & $40 \%$ \\
2 & $0 \%$ & $10 \%$ & $27 \%$ \\
3 & $0 \%$ & $5 \%$ & $13 \%$ \\
\hline
\end{tabular}

In table 4 , it is shown that students in the low mathematical ability group are not able to solve problems correctly, this happens because students are not able to understand the relationship between the two angles. Table 5 below shows the results of interviews with several respondents. 
Table 5. Results of Interviews with Respondents when Geometry Problem Implementation

\section{Low Ability Respondents}

Researcher: "Why do you think that

$$
\text { ?" } \angle \alpha=\frac{1}{3}(\angle \beta)
$$

R11: "because I think it's a comparison with

$$
" . \angle \beta
$$

Researcher: "Do you know that the angle in an equilateral triangle is 600?"

\section{Highly Skilled Respondents}

Researcher: "how did you find that

$$
\text { ?" } \angle \alpha+\angle \beta=240^{\circ}
$$

R48: "One angle in an equilateral triangle is 600 , so I'll just try the pattern. The sum of the angles in the triangle is 1800 so I just continue to pattern from the shape that is related to the ". $\angle \alpha \angle \beta$ R11: "I'm still confused about it"

Most of the students who answered incorrectly, it was due to the inability to make a relationship that $\angle \alpha+\angle \beta=240^{\circ}$ one of them was represented by $\mathrm{R} 11$. While there are also those who only find that $\angle \alpha+\angle \beta=240^{\circ}$ as done by $\mathrm{R} 48$. The other part is because it is difficult to draw conclusions from the form of comparison presented using the inequality rule. Seeing the solution options given Most students chose to use a ratio of 1: 3 , this was in accordance with what was previously predicted. Based on the results obtained, it can be seen that students have difficulty in describing the relationship of several rules to geometric shapes, even though it occurs in basic concepts.

The next issue relates to data and opportunity analysis. Students are asked to take a data by fulfilling the condition that the mean median mode. This is important given to students in order to get an idea of the extent to which students understand the interrelationships between concepts about mean, median, and mode. Not only that, this question can also measure how students perform simple data analysis. The following questions are presented related to the concept of data analysis and opportunities.

Given a data the mathematical value is $1,3,4,2,5,6$, dan $P$. calculate the integer value of $\mathrm{P}$ to satisfy condition mean $<$ median $<$ mode.

Figure 4. Problems about the Concept of Data Analysis and Opportunities

In Figure 4, it can be seen that students are asked to determine a data to meet a condition where, the mean $<$ median $<$ mode. In this problem, it will be seen how students analyze the relationships between the mean, median, and mode values of a group of data. The way students make these decisions will clearly show their analytical abilities. The application of this problem will also measure and make it easier to see the analytical skills of students with low, medium, and high abilities. An important step that must be taken in solving the problem is sorting the data presented first. Then estimate the correct location for the $\mathrm{P}$ value. There are two possible locations for the correct $\mathrm{P}$ value so that the mean $<$ median $<$ mode condition can be met. 


\begin{tabular}{|c||c|}
\hline The data is sorted as follows & The data is sorted as follows \\
$1,2,3,4,5,6$ & $1,2,3,4,5,6$ \\
The location of the $\mathrm{p}$ value that & The location of the $\mathrm{p}$ value that \\
is fulfilled so that & is fulfilled so that \\
mean $<$ median $<$ mode is & mean $<$ median $<$ mode is be \\
after data 6 so that the data is & in between data 5 and 6 so that \\
obtained & the data is obtained \\
$1,2,3,4,5,6, \mathrm{P}$ & $1,2,3,4,5, \mathrm{P}, 6$ \\
Value of $\mathrm{P}=6$ & Value of $\mathrm{P}=5$ \\
Solution 1 & Solution 2 \\
\hline
\end{tabular}

Figure 5. Solution of Data Analysis Problems and Opportunities

Based on Figure 5, there are two solutions that can be accessed by students in placing $\mathrm{P}$ data in the data group. Solution 1 is a solution that is likely to be accessed by many students by placing P after 6, but this will be an important consideration for students because when $\mathrm{P}$ is placed after 7 it can be filled with $6,7,8,9,10$, and so on. In order to fulfill the condition that the mode value is maximum, then $\mathrm{P}$ must be equal to 6 . Then in solution 2, placing $\mathrm{P}$ between 5 and 6 can be filled with 5 and 6 . This problem is important to analyze how students' ability to understand the relationship between the concepts of mean, median, and mode. Other than that, This method is used to see how students make judgments in making decisions in order to meet certain conditions. The following are the results of the implementation of the data analysis problems and opportunities presented to students.

Table 6. Results of Implementation of Data Analysis Problems and Opportunities

\begin{tabular}{cccc}
\hline Solution Type & $\begin{array}{c}\text { Low Ability } \\
\text { Respondents }\end{array}$ & $\begin{array}{c}\text { Medium Ability } \\
\text { Respondent }\end{array}$ & $\begin{array}{c}\text { Highly Skilled } \\
\text { Respondents }\end{array}$ \\
\hline 0 (wrong answer) & $40 \%$ & $25 \%$ & $0 \%$ \\
1 & $33 \%$ & $40 \%$ & $27 \%$ \\
2 & $27 \%$ & $35 \%$ & $73 \%$ \\
\hline
\end{tabular}

Table 4 shows that most students are able to solve problems well. Solution 1 is the solution that is chosen by many students with low and medium mathematical abilities. This is because by putting $\mathrm{P}=6$ it will have the same mode as 6 as well. Students who answered using solution 1 on average did not consider the mean and median values of the data given the same as that done by R08 and R30. Only students with high abilities answered using solution 1 which strengthened their assumptions by calculating the mean 
and median of the data presented. Therefore, some of the respondents who answered with solution 1 only considered the value of the mode. The following table 7 shows the results of interviews with several respondents.

Table 7. Results of Interviews with Respondents when Data Analysis Problem Implementation

\begin{tabular}{cc}
\hline Low Ability Respondents & Medium Ability Respondent \\
\hline Researcher: "why did you take the P = 5?" & Researcher: "You can get a value that $\mathrm{p}=$ \\
R08: "because of the value of the mode". & 6, why?" \\
$\begin{array}{cc}\text { Researcher: "Why don't you just take the 6 } & \text { R30: "The mode is bigger than the mean } \\
\text { mode?" } & \text { and the median, okay, I think p=6". } \\
\begin{array}{c}\text { R08: "I'm afraid the value of the mode is too } \\
\text { big than the mean and the median". }\end{array} & \begin{array}{c}\text { Rearcher: "Did you calculate the mean } \\
\text { or median value?" }\end{array} \\
& \text { R30: "I no longer calculate the mean and } \\
\text { median values, just go straight to it" }\end{array}$ \\
\hline
\end{tabular}

More interesting results are obtained when students answer with solution 2, students make good judgments about the existence of the mean and median values of the data. Students do estimates well with the intention that the mean obtained from the data is minimal, the data that students take as P must be minimal, but must be more than 4 . The application of this problem can finally show how students' ability to analyze data in order to obtain a condition related to the size of the data concentration.

\section{CONCLUSION}

Based on the research results obtained, it can be concluded that the problems presented to obtain an overview of students' mathematical abilities are related to the ability to understand algebra, the ability to conceptualize geometry, and the ability to analyze data and opportunities. In the implementation of the three problems presented, the results show that students with moderate and low mathematical abilities have low mathematical analysis and understanding abilities, this is reflected in how students take problem solving solutions. For students with high mathematical ability, their ability to analyze and relate the relationship between concepts is good, although there are some things that still need to be improved. 
138 Diagnostic Of Student Mathematics Ability On The Implementation Of MathematicsBased Assessment Open-Ended Problems

\section{THANK-YOU NOTE}

In this section, the researcher would like to express his deepest gratitude to the entire academic community of STKIP Yasika Majalengka who have helped the process of this research. Not only that, the researcher would also like to thank all respondents and schools who have accepted the research.

\section{BIBLIOGRAPHY}

Alderson, J. C., \& Huhta, A. (2005). The development of a suite of computer-based diagnostic tests based on the Common European Framework. Language Testing, 22(3), 301-320. https://doi.org/10.1191/02655322051t310oa

Anggara, B. (2019). Desain Pembelajaran Matematika pada Konsep Dasar Peluang Berbasis Kearifan Lokal Indramayu. JNPM (Jurnal Nasional Pendidikan Matematika), 3(2), 223. https://doi.org/10.33603/jnpm.v3i2.2377

Anggara, B. (2020). Pengembangan Soal Higher Order Thinking Skills Sebagai Tes Diagnostik Miskonsepsi Matematis Siswa Sma. ALGORITMA: Journal of Mathematics Education, 2(2), 176-191. https://doi.org/10.15408/ajme.v2i2.18387

Anggara, B., Priatna, N., \& Juandi, D. (2018). Learning difficulties of senior high school students based on probability understanding levels. Journal of Physics: Conference Series, 1013(1), 12116. https://doi.org/10.1088/1742-6596/1013/1/012116

Anggara, B., \& Wandari, W. (2021). Misconceptions of senior high school students in solving high-order thinking skills questions. Journal of Physics: Conference Series, 1918(4), 042089. https://doi.org/10.1088/1742-6596/1918/4/042089

Becker, J. P. (2006). The "open approach" to teaching school mathematics. Journal of the Korea Society of Mathematical Education Series D: Research in Mathematical Education, 10(3), 45-62. http://www.ksme.info/eng/html/sub03_06.asp

Djahuno, S. (2016). Pengembangan soal-soal open-ended pada pokok bahasan barisan dan deret bilangan di kelas IX a SMP Negeri 2 Tolitoli. Jurnal Kreatif Tadulako Online, 4(6), 272-281. http://jurnal.untad.ac.id/jurnal/index.php/JKTO/article/view/6139

Hadi, S., Ismara, K. I., \& Tanumihardja, E. (2015). Pengembangan Sistem Tes Diagnostik Kesulitan Belajar Kompetensi Dasar Kejuruan Siswa Smk. Jurnal Penelitian Dan Evaluasi Pendidikan, 19(2), 168-175. https://doi.org/10.21831/pep.v19i2.5577

Heddens, J. W., \& Speer, W. R. (2000). Today's mathematics: Concepts and classroom methods (eight). Macmillan Publishing Company.

Menis, J., \& Fraser, B. J. (1992). Chemistry Achievement among Grade 12 Students in Australia and the United States. Research in Science \& Technological Education, 10(2), 131-141. https://doi.org/10.1080/0263514920100202

Mustikasari, M., Zulkardi, Z., \& Aisyah, N. (2013). Pengembangan Soal-Soal Open-Ended Pokok Bahasan Bilangan Pecahan Di Sekolah Menengah Pertama. Jurnal Pendidikan Matematika, 4(2), 45 - 53. https://doi.org/10.22342/jpm.4.2.820.

Nohda, N. (2000). A study of "Open-Approach" Method in School Mathematics TeachingFocusing on Mathematical Problem Solving Activities. In Proceedings of the Ninth International Congress on Mathematical Education (Vol. 9). 
Pelfrey, R. (2000). Open-Ended Questions for Mathematics. Arsi Gold.

Ruslan, A. S., \& Santoso, B. (2013). Pengaruh Pemberian Soal Open-Ended Terhadap Kemampuan Penalaran Matematis Siswa. Kreano, Jurnal Matematika KreatifInovatif, 4(2), 138-150. https://doi.org/10.15294/kreano.v4i2.3138

Sawada, T., Shimada, S., \& Becker, J. P. (1997). Developing Lesson Plans. NCTM.

Shimada, S., \& Becker, J. P. (1997). The Open-ended Approach: A New proposal for Teaching Mathematics. NCTM.

Suherman, E., \& dkk. (2003). Common Textbook (ed.revisi). Strategi Pembelajaran Matematika Kontemporer. JICA UPI.

Suparno, P. (2013). Miskonsepsi dan Perubahan Konsep dalam Pembelajaran Fisika. Gramedia Widiasarana Indonesia.

Wandari, W., \& Anggara, B. (2021). Analysis of students difficulties in completing mathematical communication problems. Journal of Physics: Conference Series, 1918(4), 042090. https://doi.org/10.1088/1742-6596/1918/4/042090

Wiryanto. (2020). Proses Pembelajaran Matematika Di Sekolah Dasar Di Tengah Pandemi COVID-19. Jurnal Review Pendidikan Dasar: Jurnal Kajian Pendidikan Dan Hasil Penelitian, 6(2), 12 - 20.

Yusliardi, D., \& Somakim. (2015). Pengembangan Soal Open-ended Pokok Bahasan Barisan dan Deret Bilangan untuk Siswa SMP. Jurnal Elemen, 1(2), 106 - 118. 